\title{
Open Educational Resources in Higher Education
}

\author{
Margherita Berti \\ The University of Arizona
}

\begin{abstract}
Open Educational Resources (OERs) are changing the learning and teaching landscape in many different fields. In the area of higher education, OERs are swiftly becoming important elements in support of Open Educational Practices (OEPs) and the Open Education Movement. Research suggests that OERs and OEPs might be powerful vehicles for professional development, for teacher collaboration, and to enhance knowledge of technology in language pedagogy (Borthwick \& Gallagher-Brett, 2014). Nonetheless, in spite of the increasing popularity of open education, little is known with regard to the production and use of OERs in languages other than English (Zancanaro \& Amiel, 2017). This paper examines concepts, advantages and challenges related to Open Education and briefly reviews studies which discussed the production of OERs in languages other than English in higher education. The few studies addressing the development and use of OERs in languages other than English show that more research is needed to increase visibility of open education for less prominent languages and to support the Open Education Movement in higher education.
\end{abstract}

Keywords: OERs; Open Education; Educational Technology; Higher Education

\section{Open Educational Resources in Higher Education}

Open education is an emerging trend facilitated by the confluence of technology and imagination. Whether it is the K12 context or higher education, more and more individuals and organizations are exploring the potential of Open Educational Resources (OERs) and Open Educational Practices (OEPs) in education. Although OERs are understood differently by diverse communities, in 2015 UNESCO defined them as "educational resources that are openly available for use by educators and students, without an accompanying need to pay royalties or license fees" (p. 5), a definition shared and supported by many scholars (e.g., Chiappe \& Adame, 2018; Holotescu, Vlaicu, Grosseck, \& Malita, 2016; Rushby \& Surry, 2016). OERs include an extensive range of digital materials, starting from basic ones such as classroom activities and quizzes, to more elaborated resources, including textbooks, multimedia applications and course models. The educational value of OEPs and OERs lies in the idea of using open-access materials as fundamental components of the scholastic curriculum. Those materials are characterized by the opportunity of being 
shared via the Internet when digitalized. Distinct from other resources, OERs include a license, usually called Creative Commons License, that encourages the reuse, and potentially the adaptation, of materials without first requesting and obtaining permission from the creator (Butcher, 2015).

As explained by the European Commission's Science and Knowledge Service (n.d.), open education is a way of carrying out instruction using digital technologies, with the goal of broadening participation by removing geographical barriers and granting access to everyone. This open ideology makes learning accessible and equitable. Open education, OERs and OEPs offer multiple ways of teaching, learning, building, customizing, and sharing knowledge. Today, technology tools provide access to formal and informal education and stakeholders, such as learners, teachers, policymakers and administrators, who should explore ways to support open education and help students succeed. With OERs it is possible to reduce or eliminate the cost of textbooks, thus making higher education more affordable. While textbooks are generally recognized as important learning resources, published surveys of college students have shown that only a small percentage of students read the assigned textbook (Berry, Cook, Hill, \& Stevens, 2010) or buy the required materials. In a survey of more than 20,000 postsecondary students in Florida, more than half students reported that the high cost of required textbooks determined their choice to not purchase them (Hilton, 2016). Whilst the cost of textbooks is a clear problem in advanced economies, it becomes yet a bigger issue in developing countries where there is a lack of teacher-training programs, where resources for instructors are scarce, or where access to formal classrooms is limited. OERs represent one remedy to those issues by enabling the learn-from-anywhere approach, which is especially useful for students who have family and work obligations. Open education has great potential to support educational transformation in today's digital age.

\section{OERs and OEPs: Emerging Opportunities}

Several projects and initiatives have been undertaken to promote open education in higher education. The advantages and limitations of OERs have been investigated by many scholars and researchers who support collaboration and the sharing of knowledge. While the open education movement originated in the late 1990s, it attracted significant attention in 2002 when the Massachusetts Institute of Technology (MIT) released 50 freely available courses through the OpenCourseWare (OCW) initiative, first launched in 2001. Only one year after the 50 free courses were launched, MIT officially opened the MIT OCW with 500 online courses. As explained on their website (n.d.), "through OCW, educators improve courses and curricula making their schools more effective, students find additional resources to help them succeed, and independent learners enrich their lives and use the content to tackle some of our world's most difficult challenges" (para. 2). OEPs and OERs explicitly promote the " $5 R$ " activities: retain, revise, remix, reuse and redistribute. Through a process of adaptation, combination, replication and improvement, OERs offer unique opportunities in education. 


\section{The Concept of "Openness" and the Goals of OERs}

The idea of open resources comes from established movements, such as Open Access (OA) and Open Source Software (OSS) (Hylén, 2006). Although OERs are less popular than OA and OSS, they have attracted the interest of teachers and scholars who are in favor of open education. One relevant aspect of OERs is the concept of "openness," a term that implies no costs, but is not necessarily without conditions (Tuomi, 2006). The definition of openness is constantly changing and varies according to people, domains and contexts (e.g., sharing software source code, using and reusing content, open access to publications, etc.). The openness movement is based on the idea that knowledge can and should be disseminated freely, and people should benefit from such free knowledge (Largo, 2011). Tuomi (2006) argues that openness is about the right to modify, repackage and add value to existing resources. While compelling, Tuomi's definition of openness creates a new and ambiguous relationship between the consumer role and the producer role, suggesting that in open education the consumer becomes the producer, and the producer becomes the consumer without a clear distinction between the two.

Another important factor related to OERs is the level of openness that materials can have both from a format perspective and license perspective. As explained by Hylén and Schuller (2007), digital resources need to be published in a format that makes it possible to copy and paste pieces of text, images, graphics or any published media, so that they can be adapted or modified by the user. This means that non-editable formats, for instance Adobe Portable Document Format (.pdf) or Flash (.swf), do not qualify for a high level of openness. Open formats such as Hyper Text Markup Language (HTML), Portable Network Graphics (.png), and OpenDocument Format (.odf) are more open, although they might be difficult to use and thus they might exclude people lacking technology skills.

From a license standpoint, the availability of content with little or no restrictions is a crucial aspect of the Open Education Movement and the Internet offers infinite possibilities for sharing, using and reusing knowledge (Piedra, Chicaiza, López, Caro, \& Martinez, 2011). Creative Commons created a flexible set of licenses that facilitates the sharing of resources. Some examples of Creative Commons Licenses are "attribution," "attribution-noncommercial," and "attribution-noncommercial-noderivs." The first license allows others to distribute, remix, tweak, and build upon another person's work, even commercially, as long as the creator is recognized; this is the most open license, recommended for maximum dissemination and use of materials. The second example, "attribution-noncommercial," allows others to remix, tweak, and build another person's work non-commercially, with the acknowledgment of the creator. The last example listed above is the most restrictive of the Creative Commons' six main licenses, and it only allows others to download and share another person's work as long as they credit the creator. When the "attribution-noncommercial-noderivs" is applied to a digital resource, people cannot change or commercially use the resource.

A popular advocate of open education and professor at Rice University, Richard Baraniuk (2007), describes the goals and values of this movement by affirming that knowledge 
should be free and open to use and reuse, people should receive credit for contributing to education, collaboration should be easier not harder, and "concepts and ideas are linked in unusual and surprising ways and not the simple linear forms that today's textbook present" (p. 229). OEPs and the virtually unlimited OERs available on the Internet aid teachers in the creation of content sequences which will best suit the needs of students, which is one of the objectives of open education. Yuan, MacNeill, and Kraan (2008) illustrate some of the most relevant goals of OERs. The first goal is to encourage educators and learners to actively participate in the emerging open education movement by creating and integrating digital resources in education. The second goal is to publish materials in easy-to-use and revisable formats to support the sharing of knowledge. Last, OERs aim to inspire governments, school boards, colleges and universities to make open education a high priority.

Promoting collaboration is central to open education, and an important goal is to eliminate barriers, whether they refer to geographical limits, high monetary costs, legal mechanisms that prevent collaboration among scholars, or outdated materials. As argued by the Open Education Consortium, sharing is probably the most basic characteristic of education; education means sharing knowledge and information with others, setting a foundation upon which new skills, knowledge, and understanding can be built. In contrast with free resources, which can be accessed at no cost but cannot be remixed or revised, OERs are open materials which support sharing and can also be revised and mixed with other open resources or self-generated content to produce new materials that directly target learners and teachers' needs.

\section{The Potential Benefits of Open Education}

D'Antoni (2009) summarized the potential benefits of OERs according to various stakeholder perspectives. This categorization can be used to comprehend how open education affects individuals with different roles, such as learners, educators, institutions and the government. Table 1, adapted from Hodgkinson-Williams (2010), illustrates how various parties can benefit from OERs and OEPs.

Table 1.

Potential Benefits of OERs from Different Perspectives

\begin{tabular}{ll}
\hline \multicolumn{1}{c}{ Stakeholder } & \multicolumn{1}{c}{ Potential benefit } \\
\hline $\begin{array}{l}\text { Government's } \\
\text { perspective }\end{array}$ & $\begin{array}{l}\text { Widening participation in higher education by expanding access to } \\
\text { nontraditional learners }\end{array}$ \\
& $\begin{array}{l}\text { Leveraging taxpayers' money by sharing and reuse between } \\
\text { institutions } \\
\text { - }\end{array}$ \\
& Bridging the gap between formal and informal education \\
& Advancing knowledge by unlocking information for the benefit of \\
& all
\end{tabular}

(Continued) 
Table 1.

Potential Benefits of OERs from Different Perspectives (continued)

\begin{tabular}{|c|c|}
\hline Stakeholder & Potential benefit \\
\hline $\begin{array}{l}\text { Institution's } \\
\text { perspective }\end{array}$ & $\begin{array}{l}\text { - Improving recruitment by helping students find the right programs } \\
\text { - Increasing collaboration among students, faculties and other } \\
\text { institutions } \\
\text { - Attracting alumni as life-long learners } \\
\text { - Enhancing the public image of the institution }\end{array}$ \\
\hline $\begin{array}{l}\text { Educator's } \\
\text { perspective }\end{array}$ & $\begin{array}{l}\text { - Preserving a record of teaching innovations allowing others to } \\
\text { build upon them } \\
\text { - Fostering connections with colleagues around the world } \\
\text { - Gaining publicity through increased reputation } \\
\text { - Leaving a legacy after leaving academia }\end{array}$ \\
\hline $\begin{array}{l}\text { Learner's } \\
\text { perspective }\end{array}$ & $\begin{array}{l}\text { - Accessing high-quality materials from some of the best universities } \\
\text { in the world } \\
\text { - Engaging in informal learning, where credentials are not needed } \\
\text { - Saving money on expensive required textbooks } \\
\text { - Learning through updated materials that are relevant to current } \\
\text { issues }\end{array}$ \\
\hline
\end{tabular}

\section{Examples of OERs}

Today a variety of OERs can be found on the Internet. Instructors can access, modify and use numerous digital materials in their own courses, whether face-to-face or online. Learners can use the same resources to support their individual learning process and strengthen their content knowledge on a topic of interest. Some well-known examples of OERs are:

- OpenStax, a nonprofit based at Rice University, whose mission is to improve student access to education. This platform offers 29 books for college and advanced placement courses. Those books are used by hundreds of thousands of college students across the United States (https://openstax. org).

- Minnesota Open Textbook Library, described as a solution to the high annual cost of textbooks that students have to face. This platform provides a growing 
catalog of free, peer-reviewed, and openly-licensed textbooks (https://open. umn.edu/opentextbooks).

- Saylor Academy, a nonprofit initiative launched in 2008 which aims to offer free and open online textbooks and courses to all those who want to learn (https://www.saylor.org).

- Community College Consortium for Open Educational Resources, which promotes the awareness and adoption of open educational policies, practices, and resources at community colleges and technical colleges (https://www. cccoer.org).

- Open Yale Courses, which provides materials and lectures, taught by distinguished teachers and scholars at Yale University, to the public free of charge via the Internet. The courses span from liberal arts disciplines to physical and biological sciences (https://oyc.yale.edu).

- MIT OpenCourseWare, previously mentioned, is the pioneer higher institution of the OERs sharing culture with the mission of advancing knowledge and educating students in service to the nation and the world (https://ocw.mit. edu/index.htm).

- Carnegie Mellon Open Learning Initiative, which offers innovative online courses to anyone who wants to learn or teach. The aim is to create highquality courses, improve learning and transform higher education (http://oli. cmu.edu).

- Tidewater Community College, which offer Z-courses (zero courses) meaning that no textbooks are required, giving students a great return on their educational investment (https://www.tcc.edu).

From the resources listed above, which are only a few compared to the multitude available on the web, it is evident that many higher education institutions are actively involved in the creation and distribution of OERs, with the objective of improving educational outcomes and advancing the scholarship and practice of learning and teaching. Many e-learning courses harness OERs, materials that have become a valuable opportunity to foster access to high-quality education. In these online communities, professionals come together to share their knowledge and expertise in teaching while learners access information that would be costly otherwise.

It is not surprising that many universities are shifting towards OERs to make college affordable. According to the National Association of College Stores, during the 2016-17 academic year, students spent an average of $\$ 579$ on required course materials and $\$ 506$ on technology and school supplies. Although students' spending on required textbooks has decreased $\$ 23$ from the previous academic year, college students are still facing high-priced materials that they must buy to succeed in their courses. With nine out of ten faculty members reporting that they assign required materials for the classes they teach 
(National Association of College Stores, 2017), when selecting or recommending course materials, it is important to consider the cost to students.

\section{Important Challenges}

The progress of OERs has been steady over the past decade, and today there are innovative and open education initiatives across the globe. Although open education brings opportunities and advantages to many people, there are some critical issues that should be addressed when considering the use of open resources in higher education. For instance, Blessinger and Bliss (2016) argue that today higher education is limited by an educational institution's capacity; thus, it is available only to a portion of society, while a significant part of the population is left without access.

Some critical challenges, or inhibitors, concerning OERs are related to the technical, economic, social and legal domains. Although opening up education increases social equitability by providing access to resources at any time and nearly anywhere, broadband and other technology tools, necessary to access OERs, might not be available to everyone. Additionally, some people, including students and instructors might lack the technical skills needed to operate the technology devices to find and use open digital materials. Thus, it is important that institutions have experts and strategies in place to help faculty members as well as students transition towards the use of OERs.

From an economic perspective, it might be challenging to support and sustain the longterm development of OERs. First, finding high-quality OERs on the Internet might be time consuming for educators who might not get paid for such effort (Kanjilal, 2013). Furthermore, the lack of monetary resources to be invested in broadband, hardware and software as well as difficulties in covering the cost of the creation of OERs might discourage instructors and institution in embracing open education. Raising funds to undertake open education research and develop strategies to provide an income stream for OERs might be effective actions to address economic issues.

Some teachers might also be unwilling to share intellectual property, or they might not feel satisfied and thus may be reluctant to use resources produced by others (HodgkinsonWilliams, 2010). These problems are part of the social domain. Informing administrators and instructors about the numerous benefits of OERs and discussing research regarding open education might help scholars understand how the Open Education Movement can bring advantages to various stakeholders and support the sharing of knowledge.

Last, in the legal domain some potential challenges are the lack of awareness among academics regarding copyright issues and the modification of materials that present a restrictive license and do not allow alterations. To address these problems, it is important to provide instructors with professional development opportunities so that they gain a deeper understanding of how OERs and Creative Common Licenses work. The Open 
Education Movement brings dramatic changes in learning and teaching patterns, although not without challenges (Hodgkinson-Williams, 2010). As stated by Blessinger and Bliss (2016), "ensuring a high standard of education for all learners through open education means their inclusion in lifelong learning processes, the attainment of human potential and achievement of meaningful knowledge" (p. 168). OERs favor social collaboration, equality of access for learners, and create an innovative educational culture. New and emerging technologies support this movement and can be the means to serve great ideas and the future of higher education.

\section{Production and use of OERs in languages other than English}

The opportunity to learn is everyone's right, and by providing open access to education and knowledge societies can enable people to fulfill this human right. Open education is an approach that institutions and individuals can use to address today's challenges and seize the opportunities of the future. Technology tools and e-learning offer potential solutions to geographical barriers by giving a global audience unprecedented access to free, open and high-quality educational resources (Blessinger \& Bliss, 2016). Nonetheless, most OERs found on the Internet are produced and targeted to English speakers. Zancanaro and Amiel (2017) argue that a substantial imbalance exists in the availability of open educational content in less-spoken languages. While some studies focus on OERs produced for less commonly taught languages, like Portuguese (e.g., Cobo, 2013, Zancanaro \& Amiel, 2017), the paucity of studies exploring the production and use of OERs for languages other than English is alarming. Less-prominent languages might suffer from a lack of academic enrollments and global discoverability; thus, it is important to discuss how scholars and researchers have developed, used and implemented OERs in other than English higher education courses and what benefits such resources have generated for teachers and students.

According to Dixon and Hondo (2014), OERs are viewed as a mechanism for instructional innovations, and an example in the field of language learning is "Deutsch Interaktiv," a free online self-learning program for beginning and intermediate German students. As stated by Dixon and Hondo (2014), Deutsch Interaktiv fulfills many of the main requirements of an OER and has the potential to produce changes in educational practices. On this platform there are authentic digital videos, slideshows, audio texts, and an overview of the culture and language in Germany, Austria and Switzerland. The choice of materials and the sequence of course content were planned in accordance with the Common European Framework (CEFR), an international standard for the description of language ability. Deutsch Interaktiv is based on the specifications for the language proficiency levels from A1 to B1 on the CEFR scale. Similar to Deutsch Interaktiv, Français Interactif is an OER developed by the University of Texas at Austin as part of a beginner hybrid French course. Blyth (2009) explains that Français Interactif illustrates openness in many of its unique features, including an open development process based on feedback from a community of users, an open license and a modular design. 
Some scholars have examined how OERs are being explored, created and used in academia. Zancanaro and Amiel (2017) conducted a systematic analysis of published research on the theme of OERs in Portuguese. The authors aimed to boost collaboration between educators who support the open education movement but might be unaware of others working in such area. They reviewed 107 publications, selected from 64 different sources. Although their findings show that publications regarding OERs and open education in scientific journals have increased over time, the number of produced articles from 2007 to 2015 concerning Portuguese is still small. Cobo (2013) argues that research and debates related to open education mainly focus on English-speaking communities and this trend creates a barrier to guaranteeing the universal use or understanding of content for non-English speakers. Another study looked at how OEPs and OERs can support vulnerable languages, for example Dutch in the UK, and according to the author OERs provided efficiency savings and supported less-widely taught languages (Tiedau, 2013). Nonetheless, overall research exploring open education for languages other than English are scarce. Meneghini and Packer (2007) argue that English "has become the modern lingua franca in a world that is economically, scientifically and culturally largely dominated by Anglo-American countries. Any scientist must therefore master English to obtain international recognition and to access relevant publications" (p. 112). Although this might be true today, the advancement of technologies and the increasing accessibility of digital materials can support the development, spread and use of OERs and OEPs in languages other than English, thus promoting a diversified education.

\section{Conclusions}

The ideology behind OEPs and OERs is changing the way education is perceived and understood today. Much work on OERs in the higher education context has taken place, and the potential to transform the global educational landscape is immense (Olcott $\mathrm{Jr}$, 2012). As illustrated above, many open and free-to-use websites and resources exist on the Internet. Blessinger and Bliss (2016) affirmed that opening up education requires a change in attitudes and mindset that emphasize flexible growth instead of fixed traditions. In an English-dominated world, many available OERs are specific and targeted to English speakers and learners. Other languages, such as Portuguese and Dutch, might undergo a decrease in learners and might lack global discoverability if open resources are not produced, used and shared in such languages. Given the benefits and advantages that e-learning and technology tools bring to education, it is important to further discuss and share how OERs can be developed and used in courses other than English in higher education. 


\section{References}

Baraniuk, R. (2007). Challenges and opportunities for the open education movement: A connexions case study. In T. liyoshi \& M. S. V. Kumar (Eds.), Opening up education. Boston: MIT Press.

Berry, T., Cook, L., Hill, N., \& Stevens, K. (2010). An exploratory analysis of textbook usage and study habits: Misperceptions and barriers to success. College Teaching, 59(1), 31-39.

Blessinger, P., \& Bliss, T. J. (Eds.). (2016). Open education: International perspectives in higher education. Cambridge: Open Book Publishers.

Blyth, C. (2009). From textbook to online materials: The changing ecology of foreign language publishing in the era of digital technology. In M. Evans (Ed.), Foreign language learning with digital technology (pp. 179-202). London: Continuum.

Borthwick, K., \& Gallagher-Brett, A. (2014). 'Inspiration, ideas, encouragement': Teacher development and improved use of technology in language teaching through open educational practice. Computer Assisted Language Learning, 27(2), 163-183.

Butcher, N. (2015). A basic guide to open educational resources (OER). Vancouver: Commonwealth of Learning (COL).

Chiappe, A., \& Adame, S. I. (2018). Open Educational Practices: A learning way beyond free access knowledge. Revista Ensaio: Avaliação e Políticas Públicas em Educação, 26(98), 213-230.

Cobo, C. (2013). Exploration of open educational resources in non-English speaking communities. The International Review of Research in Open and Distributed Learning, 14(2), 106-128.

D'Antoni, S (2009). Open Educational Resources: reviewing initiatives and issues. Open Learning: The Journal of Open and Distance Learning, 24(1), 3-10.

Dixon, E. M., \& Hondo, J. (2014). Re-purposing an OER for the online language course: a case study of Deutsch Interaktiv by the Deutsche Welle. Computer Assisted Language Learning, 27(2), 109-121.

Hilton, J. (2016). Open educational resources and college textbook choices: A review of research on efficacy and perceptions. Educational Technology Research and Development, 64(4), 573-590.

Hodgkinson-Williams, C. (2010). Benefits and challenges of OER for higher education institutions. Paper presented at the Open Educational Resources (OER) Workshop for Heads of Commonwealth Universities, Cape Town, South Africa. 
Holotescu, C., Vlaicu, L., Grosseck, G., \& Malita, L. (2016). Recommendations on the development, implementation, certification, quality assessment and business models for MOOCs in Romania. Retrieved April 20, 2018, from https://novamooc.uvt.ro/wp-content/uploads/2017/10/Policy-recommendatiosnNOVAMOOC-2017.pdf

Hylén, J. (2006). Open educational resources: Opportunities and challenges. Paper presented at Open Education, Logan, UT.

Hylén, J., \& Schuller, T. (2007). Giving knowledge for free. The emergence of open educational resources. Retrieved April 20, 2018 from http://www.oecd.org/ dataoecd/35/7/38654317.pdf

Kanjilal, U. (2013). Digital repository to Open Educational Resource repository: IGNOU's eGyanKosh. Retrieved April 20, 2018, from http://oasis.col.org/bitstream/ handle/11599/23/pub_PS_OER_Asia_web.pdf

Largo, F. L. (2011). La biblioteca universitaria como difusor de la innovación educativa. estrategia y política institucional de la universidad de Alicante. ARBOR Ciencia, Pensamiento y Cultura, 187, 89-100.

McAndrew, P. (2010). Defining openness: Updating the concept of "open" for a connected world. Journal of interactive Media in Education, 2010(2), 1-13.

Meneghini, R., \& Packer, A. L. (2007). Is there science beyond English?: Initiatives to increase the quality and visibility of non-English publications might help to break down language barriers in scientific communication. EMBO reports, 8(2), 112116.

National Association of College Stores (2017). Retrieved April 20, 2018, from http:// www.nacs.org/research/studentwatchfindings.aspx

Olcott Jr, D. (2012). OER perspectives: Emerging issues for universities. Distance Education, 33(2), 283-290.

Piedra, N., Chicaiza, J., López, J., Caro, E. T., \& Martinez, O. (2011). Finding OERs with social-semantic search. Paper presented at the IEEE Global Engineering Education Conference (EDUCON).

Rushby, N., \& Surry, D. (2016). The Wiley handbook of Learning Technology. Hoboken: John Wiley \& Sons.

Tiedau, U. (2013). Open educational practices in a lesser-taught language community. Journal of e-Learning and Knowledge Society, 9(1), 47-57. 
Tuomi, I. (2006). Open Educational Resources: What they are and why do they matter. Retrieved April 20, 2018, from http://citeseerx.ist.psu.edu/viewdoc/ download?doi=10.1.1.693.9373\&rep=rep1\&type=pdf

Yuan, L., MacNeill, S., \& Kraan, W. G. (2008). Open Educational Resources. Opportunities and challenges for higher education. Retrieved April 20, 2018, from http://publications.cetis.org.uk/wp-content/uploads/2012/01/OER_ Briefing_Paper_CETIS.pdf

Zancanaro, A., \& Amiel, T. (2017). The academic production on open educational resources in Portuguese. Revista Iberoamericana de Educación a Distancia, 20(1), 81-104. 